\title{
Effect of Nitrogen Level on Herbage and Seed Yield of Rhodes Grass (Chloris gayana)
}

\author{
Mulisa Faji Dida (D), ${ }^{1}$ Alemeyehu Abebe Lemore, ${ }^{2}$ and Kedija Ahmed Seid ${ }^{2}$ \\ ${ }^{1}$ Ethiopian Institute of Agricultural Research, Holetta Agricultural Research, P. O. Box 31 Holetta, Holetta, Ethiopia \\ ${ }^{2}$ Ethiopian Institute of Agricultural Research, Assosa Agricultural Research, P. O. Box 265 Assosa, Assosa, Ethiopia \\ Correspondence should be addressed to Mulisa Faji Dida; mulisa.faji2016@gmail.com
}

Received 20 January 2021; Revised 10 February 2021; Accepted 4 March 2021; Published 12 March 2021

Academic Editor: Allen Barker

Copyright (C) 2021 Mulisa Faji Dida et al. This is an open access article distributed under the Creative Commons Attribution License, which permits unrestricted use, distribution, and reproduction in any medium, provided the original work is properly cited.

\begin{abstract}
Nitrogen is the most important macronutrient for forage and food crop production. Currently, cultivable lands in Ethiopia undergo a deficiency of this element. Thus, this study was conducted to find an appropriate rate of nitrogen (N) fertilizer for the better agronomic performance of Chloris gayana Masaba. The experiment was carried out at Assosa Agricultural Research Center. The experiment was conducted using a randomized complete block design with three replications, and the treatments were five levels of nitrogen fertilizer $(0,23,46,69$, and $92 \mathrm{~kg} \mathrm{~N} / \mathrm{ha})$. The collected data were analyzed using the general linear model procedure of SAS, and the least significance difference was used for mean separation. Plant height at forage harvesting, dry matter yield, leaf to stem ratio, leaf height, number of leaves per plant, number of tillers, and seed yield were significantly $(p<0.001)$ influenced by the year of planting while nonsignificantly $(p>0.05)$ by nitrogen fertilizer rate and interaction of planting year and fertilizer rate. The mean leaf to stem ratio was significantly $(p<0.001)$ higher in 2017 and 2018 than in the 2019 planting year. However, forage dry matter yield was significantly $(p<0.001)$ higher in 2019, followed by 2018 and 2017 planting years. Mean seed yield was significantly $(p<0.001)$ different among the establishment years and the peak seed yield productivity attained during the third year of harvesting (1st $=2 \mathrm{nd}<3 \mathrm{rd}$ year of harvesting). Generally, all measured agronomic traits were not significantly responsive to the different fertilizer rates, and in the economic point of view, $0 \mathrm{~kg}$ of $\mathrm{N} / \mathrm{ha}$ is recommended.
\end{abstract}

\section{Introduction}

Forage production is gaining more attention in the tropics and the subtropics in both developed and developing countries. New species, varieties, and cultivars of forage and pasture plants have been introduced from areas and countries rich in forage and pasture plants to areas where they are scarce [1]. However, the main feed resources for livestock in Ethiopia are natural pasture and crop residues, which are low in quantity and quality for sustainable animal production $[2,3]$. In Ethiopia, crop residues of cereals and pulses account for about $32 \%$ of the total feed utilized and ranked second to grazing (37\%) [4]. Natural pastures that provide the bulk of ruminant feed in Ethiopia are depleted from time to time, and their average annual productivity does rarely exceed $1.5-2.5 t \mathrm{ha}^{-1}$ dry matter under the continuous communal grazing system [5]. Crop residues as other major sources of livestock feed could not meet the nutritional requirements of the animals due mainly to low protein and high fiber contents. Hence, these feeds have to be complemented with cultivated pasture species of high forage yield with reasonable quality if any meaningful production level is to be expected from livestock. The shortage of feed is exacerbated by the increase in human and livestock population and the expansion of cropland, resulting in the decrement of grazing land [6]. In such situations, improved forage options that address yield and nutritive issues are needed to increase livestock productivity. This requires the introduction of high-quality cultivated forage with high yielding ability and adaptability to biotic and abiotic environmental stresses [7-9]. Much important improved forage has been generated by the research systems 
over the last years in the country. Among the improved forage cropsintroduced into Ethiopia, Chloris gayana could play an important role in providing a significant amount of yield and quality forage under smallholder farmers and intensive livestock production systems [10]. However, the yield of improved forage species can be low due to management information gaps such as application of fertilizer, irrigation, weeding, optimum spacing, and harvesting days. There is inadequate information on the management practices that influence dry matter yield and nutritive value of Chloris gayana when grown with appropriate nitrogen fertilizer and stage of harvesting. Chloris gayana Masaba species is among the Chloris gayana species selected for their adaptation and herbage yield in most parts of Ethiopia. Nitrogen fertilization develops stronger cells for photosynthesis [11]. Nitrogen fertilization benefits grasses by the decay of root nodules or mineralization of shed leaves and increases forage dry matter yield, forage quality in terms of crude protein content, voluntary feed intake, and digestibility [12]. Fertilizer application is responsible for the changes in herbage yield [11]. However, the use of fertilizers to improve forage yield is limited [13], and there should be local information to encourage forage growers to use fertilizer in forage cultivation. Tropical grasses drastically reduce in their nutritive value with an advance in the stage of harvesting. Nitrogen fertilization application is predominantly responsible for the changes in nutritive value [14]. Nevertheless, information regarding the effect of fertilizer on biomass yield and nutritive value of Chloris gayana Masaba adapted to Ethiopia is lacking. One means of enhancing the yield and quality of forage is through fertilizer application. Thus, the present study was designed to evaluate the effect of nitrogen fertilizer on herbage and seed yield of Rhodes grass (Chloris gayana Masaba) grown rain-fed in Western Ethiopia.

\section{Materials and Methods}

2.1. Study Area. The study was conducted at Assosa Agricultural Research Center which is located in BenshangulGumuz Regional State, Western Ethiopia. Assosa is located within $10^{\circ} 30^{\prime} \mathrm{N}$ latitude and $034^{\circ} 20^{\prime} \mathrm{E}$ longitude and an altitude of 1576 meters above sea level. The pattern of rain is unimodal with a mean annual rainfall of $1275 \mathrm{~mm}$. The minimum temperature varies between $14^{\circ} \mathrm{C}$ and $20^{\circ} \mathrm{C}$, and the maximum temperature ranges from $25^{\circ} \mathrm{C}$ to $39^{\circ} \mathrm{C}$. The soil type is reddish-brown nitisols [15].

2.2. Experimental Design and Materials Used. The experiment was conducted with five levels of nitrogen fertilizer rate $(0,23,46,69$, and $92 \mathrm{~kg} \mathrm{~N} / \mathrm{ha})$. The $\mathrm{N}$ fertilizer was applied when the grass was sown by drilling on the rows depending on the fertilizer treatment. Field trials were arranged in a randomized complete block design with three replications. The spacing between replication and plots was 2 and $1.5 \mathrm{~m}$, respectively. The plot size was $3 \mathrm{~m}^{*} 4 \mathrm{~m}\left(12 \mathrm{~m}^{2}\right)$. There was one year of establishment, followed by several years where the grass was harvested. The samples for dry matter and seed yield determination were harvested from four angles of each plot. During sampling at $10 \%$ flowering for dry matter yield estimation, a $1 \mathrm{~m}^{*} 1 \mathrm{~m}$ quadrate was randomly thrown at the two diagonal angles of each plot and harvested by machete from each plot, and then, it was weighed for its fresh weight right in the field. However, the other two diagonal angles of each plot were harvested at physiological maturity for seed yield estimation. Herbage samples were dried to constant weight using a forced air-drying oven to determine the dry matter percentage. Forage yield was estimated by harvesting the grasses at the stage of $10 \%$ flowering. The dry matter yield was calculated after drying a sample of $500 \mathrm{~g}$ green forage in an oven at $650 \mathrm{C}$ for 72 hours [16] in Assosa Agricultural Research Center which was converted into hectares. The plant height was measured by averaging the natural standing height of six plants per plot. The main branch number was an average of primary branches on the stem of six plants per plot. The mature inflorescences (three weeks after full flowering) were harvested $10-15 \mathrm{~cm}$ below the panicle and then sun-dried, piled for a few days, and manually threshed and cleaned to estimate seed yield. Seed yield data were taken after proper drying by sensitive balance.

2.3. Data Analysis. The data collected on agronomic traits were subjected to analysis of variance by using the general linear model (GLM) procedure in R software, and mean separation was done using the LSD test at $5 \%$ probability level. The effects of nitrogen fertilizer application rates on morphological characteristics, dry matter, and seed yield were determined using the following model: $\mathrm{Yijk}=\mu+\mathrm{Ri}+\mathrm{Nk}+$ eik, where $\mathrm{Yijk}=$ dependent variables, $\mu$ overall mean, $\mathrm{Ri}=i$ th replication of nitrogen fertilizer application rate, $\mathrm{Nk}=(\mathrm{kth} 1-4)$ level of nitrogen fertilizer application rate, and eik=error component for plot and interaction.

\section{Results and Discussion}

3.1. Effects of Establishment Years and Interaction on the Performance of Chloris gayana. A combined analysis of variance for measured agronomic traits of Chloris gayana Masaba at different levels of nitrogen fertilizer rate is presented in Table 1 . The results of this study revealed that all measured agronomic traits were significantly $(P<0.001)$ different among the establishment years, and this might be due to climatic variations between the establishment years. The level of nitrogen fertilizer rate and the interaction of establishment years and nitrogen fertilizer rate were not significantly $(P>0.05)$ influencing all measured agronomic traits of Chloris gayana Masaba.

As indicated in Figure 1, forage dry matter yield, the number of branches per plant, and the number of tillers were maintained/increased throughout the establishment years and this implies the growth performance of Chloris gayana during the first establishment year is very slow even under the regime of fertilizer application. This might be the nutrient supply in the first year of the establishment may 
TABLE 1: Effects of years of planting and interaction on measured agronomic traits of Chloris gayana.

\begin{tabular}{lcccc}
\hline S. no. & N levels $(\mathrm{N})$ & Years $(\mathrm{Y})$ & Nxy & Mean \\
\hline (1) Plant height (cm) & $\mathrm{ns}$ & $* * *$ & $\mathrm{~ns}$ & 86.38 \\
(2) Forage DM yield (t/ha) & $\mathrm{ns}$ & $* * * *$ & $\mathrm{~ns}$ & 4.70 \\
(3) Leaf to stem ratio & $\mathrm{ns}$ & $* * *$ & $\mathrm{~ns}$ & 0.71 \\
(4) Leaf height (cm) & $\mathrm{ns}$ & $* * *$ & $\mathrm{~ns}$ & 28.47 \\
(5) No. of branches per plant & $\mathrm{ns}$ & $* * *$ & $\mathrm{~ns}$ & 21.25 \\
(6) Number of tillers & $\mathrm{ns}$ & $* * *$ & $\mathrm{~ns}$ & 20.08 \\
(7) Seed yield & $\mathrm{ns}$ & $\mathrm{ns}$ & 19.82 \\
\hline
\end{tabular}

${ }^{* * *} P<0.001$

enhance more root development than vegetative biomass growth in perennial grasses. This in turn would determine the subsequent herbage or seed productivity of the species in the following production seasons. Consequently, seed yield and forage dry matter yield were shown to increase from the first year of establishment to the third year. Leaf to stem ratio was higher for the second year of establishment than the third year of establishment, and this might be because a higher mean leaf height was recorded during the second year of establishment than the third year of establishment. The number of tillers per plant showed an increment during the first year of establishment to the third year of establishment, and this might be due to the variation in climate among the establishment year. Increased tillering is probably an adaptive feature to tolerate frequent defoliation by reestablishing the lost photosynthetic areas and maintaining the basal area. In the year after establishment, rhizomes had spread in the plot increasing tiller density. High tiller production not only indicates stable productivity [17] but also is linked to better persistence after periods of unfavorable environmental conditions [18]. Similarly, the number of leaves per plant was increased with the year of establishment, and this might be due to the number of leaves per plant and the number of tillers positively correlated. Forage dry matter yield was also increased with the establishment year opposite to the leaf to stem ratio, and this might be because more stem forages are higher in dry matter yield (leaf to stem ratio negatively correlated with forage dry matter yield).

3.2. Leaf to Stem Ratio. The mean leaf to stem ratio of Chloris gayana Masaba at different levels of nitrogen fertilizer rate is presented in Table 2 . Leaf to stem ratio was not significantly $(P>0.05)$ different among the levels of nitrogen fertilizer rate across the establishment years. The result of the combined analysis revealed that the leaf to stem ratio was not significantly influenced by the level of nitrogen fertilizer rate. This observation is in accordance with those obtained in $[1,19]$, which reported that the leaf to stem ratio of Chloris gayana was not influenced by nitrogen and NPK fertilizer rate, respectively. This might be due to the fertilizer applied one dose. The mean leaf to stem ratio was significantly $(P>0.001)$ decreased from the first year of establishment to the third year of establishment, and this might be because a decrease in a leaf to stem ratio with the longer year of establishment is a function of longer periods of physiological growth with reduced defoliation frequency

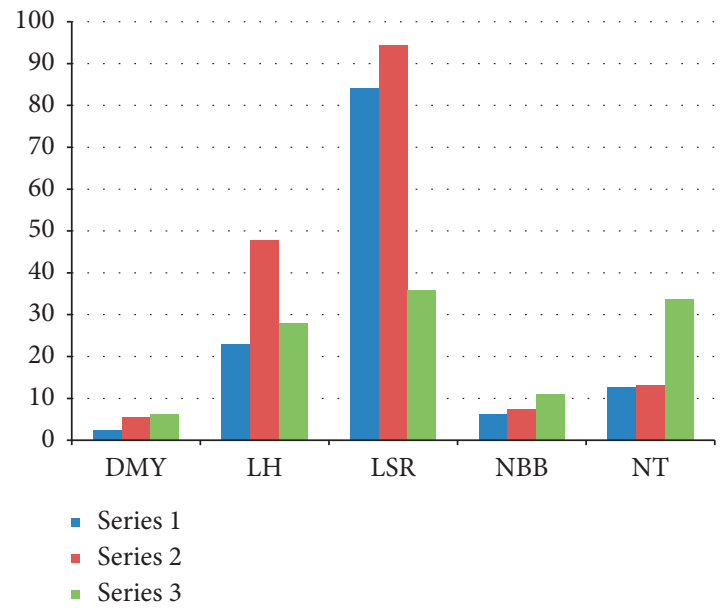

FIgURE 1: Agronomic traits over three years. DMY= dry matter yield $(\mathrm{t} / \mathrm{ha}) ; \mathrm{LH}=$ leaf height $(\mathrm{cm}) ; \mathrm{LSR}=$ leaf to stem ratio; $\mathrm{NBB}=$ number of leaves per plant; $\mathrm{NT}=$ number of tillers; series 1 = planting year 1 ; series 2 = harvesting year 2 ; series $3=$ harvesting year 3 .

stimulating stem growth at the expense of leaf production [20]. The leaf to stem ratio has significant implications on the nutritive quality of the grass as leaves contain higher levels of nutrients and less fiber than stems. The results indicated that the LSR is an important factor affecting diet selection, quality, and intake of forage [21]. The LSR is associated with the high nutritive value of the forage because the leaf is generally of a higher nutritive value [22], and the performance of animals is closely related to the number of leaves in the diet. This observation is in accordance with those obtained in $[1,19]$.

3.3. Forage Dry Matter Yield. The mean forage dry matter yield of Chloris gayana at different levels of nitrogen fertilizer rate is indicated in Table 3. Forage dry matter yield was not significantly $(P>0.05)$ influenced by nitrogen fertilizer rate difference across the year of establishment and this might be due to the early (during sowing) application of nitrogen fertilizer to the plants in one dose; therefore, the growing plants did not use the fertilizer efficiently in the late of their growth when they were at an age of 30-45 days. Although the applied nitrogen in one dose might be lost by leaching, this makes the result nonsignificant. The authors in [23] showed that a split application of nitrogen is superior to a large single application in producing a yield of warmseason grasses. Similar results were reported in [24, 25] 
TABLE 2: Mean leaf to stem ratio of Chloris gayana grass in response to different $\mathrm{N}$ fertilizer levels.

\begin{tabular}{lcccc}
\hline Treatments & \multicolumn{3}{c}{ Year } & Combined over years \\
& 2017 & 2018 & 2019 & \\
\hline $0 \mathrm{~kg} \mathrm{~N} \mathrm{ha}^{-1}$ & 0.83 & 1.07 & 0.42 & 0.77 \\
$23 \mathrm{~kg} \mathrm{~N} \mathrm{ha}^{-1}$ & 0.90 & 0.91 & 0.39 & 0.71 \\
$46 \mathrm{~kg} \mathrm{~N} \mathrm{ha}^{-1}$ & 0.87 & 0.87 & 0.34 & 0.69 \\
$69 \mathrm{~kg} \mathrm{~N} \mathrm{ha}^{-1}$ & 0.87 & 0.91 & 0.33 & 0.70 \\
$92 \mathrm{~kg} \mathrm{~N} \mathrm{ha}^{-1}$ & 0.79 & 0.95 & 0.31 & 0.69 \\
Mean & $0.85^{\mathrm{a}}$ & $0.94^{\mathrm{a}}$ & $0.36^{\mathrm{b}}$ & 0.71 \\
$\mathrm{CV}$ & 14.61 & 22.84 & 31.06 & 19.65 \\
Significance level & $\mathrm{ns}$ & $\mathrm{ns}$ & & $\mathrm{ns}$ \\
\hline
\end{tabular}

Mean with the same letter are not statistically nonsignificant, but means with different letters are statistically different.

TABLE 3: Mean forage DM yield ( $\mathrm{tha}^{-1}$ ) of Chloris gayana grass in response to different $\mathrm{N}$ fertilizer levels.

\begin{tabular}{lcccc}
\hline Treatments & \multicolumn{3}{c}{ Year } & Combined over years \\
& 2017 & 2018 & 2019 & \\
\hline $0 \mathrm{~kg} \mathrm{~N} \mathrm{ha}^{-1}$ & 1.96 & 4.65 & 7.46 & 4.69 \\
$23 \mathrm{~kg} \mathrm{~N} \mathrm{ha}^{-1}$ & 1.59 & 6.85 & 6.82 & 5.32 \\
$46 \mathrm{~kg} \mathrm{~N} \mathrm{ha}^{-1}$ & 2.88 & 5.23 & 5.74 & 4.62 \\
$69 \mathrm{~kg} \mathrm{~N} \mathrm{ha}^{-1}$ & 1.98 & 6.12 & 5.68 & 4.59 \\
$92 \mathrm{~kg} \mathrm{~N} \mathrm{ha}^{-1}$ & 3.04 & 4.71 & 5.09 & 4.28 \\
Mean & $2.38^{\mathrm{b}}$ & $5.51^{\mathrm{a}}$ & $6.17^{\mathrm{a}}$ & 4.70 \\
$\mathrm{CV}$ & 33.56 & 25.53 & 34.27 & 37.42 \\
Significance level & $\mathrm{ns}$ & $\mathrm{ns}$ & $\mathrm{ns}$ & $\mathrm{ns}$
\end{tabular}

Mean with the same letter are not statistically nonsignificant, but means with different letters are statistically different.

about the application of $\mathrm{N}$ to Rhodes grass. This result implies that the experimental soil had enough nutrients to sustain optimal performance of Chloris gayana grass either the $\mathrm{N}_{2}$ applied at $100 \mathrm{~kg} \mathrm{ha}^{-1}$ or not applied (without $\mathrm{N}_{2}$ application). Also, the nonsignificant result might be contributed to the low rate of applied nitrogen across the treatments. The results of the combined analysis also indicated that the mean forage dry matter yield was not significantly $(P>0.05)$ different among the different nitrogen fertilizer rates. In agreement with this study, Brima [1] reported that the forage dry matter yield of Chloris gayana is not influenced by the application of NPK fertilizer. The year of the establishment was significantly $(P<0.001)$ affecting the mean forage dry matter yield, and this might be attributed to the variation in climatic conditions between the years of establishment. Chloris gayana produces peak forage dry matter yield during the third year of establishment, and this might be due to fertilizer application, which enhances the production of more tillers and the number of branches per plant during the third year. This result is in agreement with the finding in [26] who reported that Napier grass could produce a peak number of tillers during the third year of establishment and that fertilizer application enhances the production of more tillers.

3.4. Seed Yield. The mean seed yield of Chloris gayana in response to different $\mathrm{N}$ fertilizer levels is presented in Table 4 . Mean seed yield was not significantly $(P>0.05)$
TABLE 4: Mean seed yield ( $\mathrm{kg}$ ha-1) of Chloris gayana in response to different $\mathrm{N}$ fertilizer levels.

\begin{tabular}{lcccc}
\hline Treatments & \multicolumn{3}{c}{ Year } & $\begin{array}{c}\text { Combined over } \\
\text { years }\end{array}$ \\
\hline $0 \mathrm{~kg} \mathrm{~N} \mathrm{ha}^{-1}$ & 2017 & 2018 & 2019 & 252.17 \\
$23 \mathrm{~kg} \mathrm{~N} \mathrm{ha}^{-1}$ & 187.00 & 199.17 & 433.20 & 256.24 \\
$46 \mathrm{~kg} \mathrm{~N} \mathrm{ha}^{-1}$ & 155.40 & 238.90 & 443.00 & 279.10 \\
$69 \mathrm{~kg} \mathrm{~N} \mathrm{ha}^{-1}$ & 167.13 & 248.20 & 440.43 & 285.26 \\
$92 \mathrm{~kg} \mathrm{~N} \mathrm{ha}^{-1}$ & 184.00 & 195.40 & 555.77 & 311.72 \\
Mean & $161.86^{\mathrm{b}}$ & $221.15^{\mathrm{b}}$ & $449.73^{\mathrm{a}}$ & 449.73 \\
$\mathrm{CV}$ & 29.96 & 18.50 & 35.95 & 34.27 \\
Significance & $\mathrm{ns}$ & $\mathrm{ns}$ & $\mathrm{ns}$ & $\mathrm{ns}$ \\
level & & & &
\end{tabular}

Mean with the same letter are not statistically nonsignificant, but means with different letters are statistically different.

affected by the variation in nitrogen fertilizer rate, and this might be due to the experimental unit on which the experiment was carried out covered by legume forage. This implies the nitrogen content of the soil is improved, and the application of nitrogen fertilizer cannot respond to the measured agronomic traits. Additionally, the nitrogen fertilizer is applied one time to plants in one dose (only during sowing), and this makes plants not get efficient fertilizer at the postestablishment. This implies the herbage and decrease in seed yield of Chloris gayana. In agreement with this study, Assefa et al. [27] reported that the time of fertilizer application has an overriding effect in addition to the rate of application in postestablishment crops. Even though the applied nitrogen might be lost by leaching, this makes the result nonsignificant. Similarly, Bogdan [28] reported that nitrogen applied as urea is expected to be lost through leaching and volatilization. The year of the establishment significantly $(P<0.001)$ influenced seed yield of Chloris gayana, and this might be due to residual effects of applied nitrogen fertilizer. Seed yield of Chloris gayana showed peak productivity during the third year of establishment. This indicates the residual fertilizer value of nitrogen in improving crop response towards the later stage of establishment. In general, the overall mean seed yield of Rhodes grass in this experiment ranged from $161.86 \mathrm{~kg}$ ha-1 to $449.73 \mathrm{~kg}$ ha-1; in taking climatic and seasonal variations into account, this yield range is in agreement with [28] which stated that, under tropical conditions, Chloris gayana produces two crops of seed per year and seed yield ranges from 65 to $650 \mathrm{~kg} \mathrm{ha}^{-1}$ year-1.

\section{Conclusion}

The overall measured agronomic traits were nonsignificant in response to the different nitrogen fertilizer rates. Therefore, in the economic point of view, $0 \mathrm{~kg} \mathrm{~N} / \mathrm{ha}$ is recommended for Chloris gayana Masaba in the study area. However, there is a need to evaluate the productivity of Chloris gayana under split application of nitrogen fertilizer since the time of application has an overriding effect in addition to the rate of application in postestablishment crops. 


\section{Data Availability}

The data used to support the findings of this study are available from the corresponding author on reasonable request.

\section{Conflicts of Interest}

The authors declare that they have no conflicts of interest.

\section{Acknowledgments}

The field research was fully financed by the Ethiopian Institute of Agricultural Research (EIAR). The authors would like to thank Assosa Agricultural Research Center for facilitating the field research work.

\section{References}

[1] F. I. A. Brima, "Effect of seed rate and NPK fertilization on growth, yield and forage quality of Rhodes grass (Chloris gayana L. kunth.)," MSc. Thesis, Department of Agronomy, Faculty of Agriculture, University of Khartoum, 2007.

[2] T. Zewdu, R. Baars, A. Yami, and D. Negassa, "In sacco dry matter and nitrogen degradation and their relationship with in vitro dry matter digestibility of Napier grass (Pennisetum purpureum Schumach.) as influenced by height of plant at cutting," Australian Journal of Agricultural Research, vol. 53, no. 1, pp. 7-12, 2002.

[3] T. Zewdu and R. M. T. Baars, "Chemical component, in vitro dry matter digestibility and Ruminal degradation of Napier grass (Pennisetum purpureum (L.) Schumach) mixed with different levels of Sesbania sesban (L.) Merr.)," Animal Feed Science and Technology, vol. 117, pp. 29-41, 2004.

[4] CSA (Central Statistical Agency), "Livestock and livestock characteristics (private peasant holdings), federal democratic republic of Ethiopia, agricultural sample survey. Statistical bulletin 578 volume 2, March 2015," pp. 322-327, CSA (Central Statistical Agency), Addis Ababa, Ethiopia, 2015.

[5] EURO, Forage and Pasture Research Strategy, EURO, Rho, Italy, 2000.

[6] G. F. Duguma, Participatory definition of breeding objectives and implementation of community based sheep breeding programs in ethiopia, $\mathrm{PhD}$ Thesis, University of Natural Resources and Life Sciences, Vienna, Austria, 2010.

[7] T. Zewdu and H. Mohammed, Seboka Deressa, Forage and pasture research achievements in north-western Ethiopia," in Proceedings Of the Fourth Technology Generation, Transfer And Gap Analysis Workshop On Agricultural Research And Technology Transfer, Attempts and Achievements in Northern Ethiopia, Bahir Dar, Ethiopia, March 1997.

[8] T. Zewdu, R. Baars, and A. Yami, "Effect of plant height at cutting, source and level of fertiliser on yield and nutritional quality of Napier grass (Pennisetum purpureum (L.) Schumach.)," African Journal of Range \& Forage Science, vol. 19 , no. 2, pp. $123-128,2002$ b.

[9] R. K. Kahindi, S. A. Abdulrazak, and R. W. Muinga, "Effect of supplementing Napier grass (Pennisetum purpureum) with madras thorn (Pithecellobium dulce) on intake, digestibility and live weight gains of growing goats," Journal of Small Ruminant Research, vol. 69, no. 1-3, pp. 83-87, 2007.

[10] WARC (Werer Agricultural Research Center), Forage and Pasture Research Program Progress Report. Werer, Ethiopia,
WARC (Werer Agricultural Research Center), Corvallis, MT, USA, 2014.

[11] M. Bob, The Good, Bad and Interesting Roles of Nitrogen and Nitrogen Fertilizers in Home Lawn Care- Part 2 of a 3 Part Series on Understanding and Using Home Lawn Fertilizers, University of Minnesota Cooperative Extension, Minneapolis, MN, USA, 2011.

[12] O. A. Aderinola, Herbage production and utilization of andropogon tectorum as influenced by fertilizer application and legume intercrop, Ph.D Thesis Department of Animal Production Health, Ladoke Akintola University Technology, Ogbomoso, Nigeria, 2007.

[13] F. G. Sodeinde, V. O. Asaolu, I. O. A. Adeleye, M. K. Adewumi, B. Oyebanji, and S. Adeniyi, "Effect of nitrogen fertilizer on the dry matter productivity of Panicum maximum and soil copper and manganese contents in the derived savannah zone of Nigeria," in Proceeding of the 31st Annual Conference of Nigerian Society for Animal Production 12th-15th March, 2006, Bayero University Kano, Nigeria, Kano, March 2006.

[14] J. Čop, M. Vidrih, and J. Hacin, "Influence of cutting regime and fertilizer application on the botanical composition, yield and nutritive value of herbage of wet grasslands in Central Europe," Grass and Forage Science, vol. 64, pp. 454-465, 2009.

[15] A. Alemayehu and T. Woldegabriel, "Condition, species composition and productivity of natural pastures of benishangul-Gumuz regional state, western Ethiopia," African Journal of Basic \& Applied Sciences, vol. 8, no. 4, pp. 220-231, 2016.

[16] ILCA (International Livestock Center for Africa), Livestock Research Manual, ILCA, Addis Ababa, Ethiopia, 1990.

[17] M. Mukhtar, "Dry matter productivity of the dwarf and normal elephant grasses as affected by the planting density and cutting frequency," Indonesian Journal of Animal and Veterinary Sciences, vol. 11, pp. 198-205, 2006.

[18] S. G. Assuero and J. A. Tognetti, "Tillering regulation by endogenous and environmental factors and its agricultural management," The Americas Journal of Plant Science and Biotechnology, vol. 4, pp. 35-48, 2010.

[19] S. A. Gasim, "Effect of nitrogen, phosphorus and seed rate on growth, yield and quality of forage maize (Zea mays L.)," M.Sc.Thesis, Faculty of Agriculture, University of Khartoum, 2001.

[20] M. N. Butt, G. B. Donart, M. G. Southward, R. D. Pieper, and N. Mohammad, "Effect of defoliation on plant growth of Napier grass," Tropical Science, vol. 33, pp. 111-120, 1993.

[21] A. J. Smart, W. H. Schacht, L. E. Moser, and J. D. Volesky, "Prediction of leaf/stem ratio using near-infrared reflectance spectroscopy (NIRS): a Technical Note," Agronomy \& Horticulture Faculty Publications, vol. 39, 2004.

[22] S. Tudsri, S. T. Jorgensen, P. Riddach, and A. Pookpakdi, "Effect of cutting height and dry season date on yield and quality of five Napier grass cultivars in Thailand," Tropical Grasslands, vol. 36, pp. 248-252, 2002.

[23] S. R. Wilkinson and G. W. Langdale, Forage Fertilization: Fertility Needs of the Warm-Season Grasses, pp. 119-143, American Society of Agronomy, Crop Science of American, Soil Science Society of American, Madison, WL, USA, 1976.

[24] M. A. M. Khair, 1999. Principles of Forage Crops Production, Agricultural Research Corporation ARC, Training and Publication Administration, Wadmadani, Sudan, in Arabic, 1999.

[25] A. O. Abusuwar, 2005. Forage Production in the Sudan, in Arabic, pp. 54-58, 2005. 
[26] F. Feyissa, G. Assefa, L. G. Hiwot, M. Minta, and T. T. Tsadik, "Evaluation of Napier grass-vetch mixture to improve total herbage yield in the central highlands," in Proceedings of the 13th Annual Conference of the Ethiopian Society of Animal Production (ESAP), Addis Ababa, Ethiopia, August 2005.

[27] G. Assefa, F. Feyissa, and A. Gebeyehu, "Effect of manure and nitrogen fertilization on establishment, herbage yield and seed productivity of perennial grasses," in Proceedings of the 10th Annual Conference of the Ethiopian Society of Animal Production (ESAP), Addis Ababa, Ethiopia, August 2003.

[28] A. V. Bogdan, Tropical Pasture and Fodder plants. Tropical Agricultural Series, Whistable Litho Ltd., Whistable, Kent, Great Britain, 1977. 